\title{
The results of surgical treatment of distal esophageal leiomyomatosis performed distal esophagectomy
}

\section{Distal özofajektomi yapılan distal özofageal leiomyomatozislerde cerrahi tedavi sonuçları}

\author{
*Mustafa Taner Bostancı, Erol Aksoy, Tahsin Dalgıç, Murat Ulaş, Mehmet Ali \\ Çaparlar, Özcem Öfkeli, İlter Özer, Erdal Birol Bostancı \\ ${ }^{1}$ Department of Gastroenterologic Surgery, Turkey Yüksek Ihtisas Hospital, Ankara, Turkey \\ Corresponding author: Dr. Mustafa Taner Bostanc1, Gastroenterolojik Cerrahi Bölümü, Türkiye Yüksek İhtisas Has- \\ tanesi, TR 06230, Ankara, Turkey. \\ E-mail: mtanerbostanci@gmail.com \\ Received/Accepted: April 01, 2014/September 11, 2015 \\ Conflict of interest: There is not a conflict of interest.
}

\section{SUMMARY}

Objective: Leiomyomas are the most common benign esophageal neoplasms. Surgical treatment is the therapy of choice for such tumors. In this study, we submitted results of 6 patients with distal esophageal leiomyomas who underwent surgical treatment during a 5-year period. The aim of the current study was to evaluate the long-term outcomes of patients with leiomyoma located at distal esophagus who had undergone distal esophagectomy and esophagogastrostomy.

Method: Demographic features, clinical and laboratory findings including symptoms, diagnosis, histopathology, and results of surgical treatment were examined.

Results: 6 patients (four women, two men; mean age 48.8y) were operated due to leiomyoma located at the lower esophagus. The most common symptoms were dysphagia and dyspepsia. Distal esophagectomy and esophagogastrostomy was performed to all patients with a median laparathomy and a right posterolateral thoracotomy. All patients were relieved from their symptoms without postoperative mortality, while pneumonia was occured in one patient which is treated medically.

Conclusions: Esophageal leiomyoma is a benign tumor which becomes symptomatic in large seizes. Surgical resection is considered to be effective for distal esophageal leiomyomas, without complications.

Keywords: Esophagus, leiomyoma, distal esophagectomy

\section{ÖZET}

Amaç: Leiomyomalar en sık görülen benign özofageal neoplazilerdir. Cerrahi tedavi bu tümörlerde seçilen tedavi șeklidir. Bu çalışmada, 5 yıllık bir sürede distal özofageal leiomyoma nedeniyle cerrahi uygulanmış 6 hastanın tedavi sonuçlarını sunduk. Çalışmadaki amacımız distal özofagus yerleşimli leiomyoması olup distal özofajektomi ve özofagogastrostomi uygulanmış 6 hastanın uzun dönem sonuçlarını değerlendirmekti.

Yöntem: Demografik özellikler, semptomlar, tanı, histopatolojiyi içerecek șekilde klinik ve laboratuar bulgular ve cerrahi tedavi sonuçları incelenmiştir.

Bulgular: Distal özofagus yerleşimli leiomyoma nedeniyle 6 hasta ( 4 kadın, 2 erkek; ortalama yaş 48.8 y1l) opere edilmiştir. Disfaji ve dispepsi en sik görülen semptomlardı. Tüm hastalara median laparotomi ve sağ posterolateral torakotomi ile distal özofajektomi ve özofagogastrostomi uygulanmıştır. Hiçbir hastada mortalite gelişmemiş olup tüm hastaların semptomlarında iyileşme olmuştur; bir hastada pnömoni gelişmiş olup medikal olarak tedavi edilmiştir.

Sonuç: Özofageal leiomyoma benign bir tümör olup büyük boyutlara ulaşınca semptomatik hale gelir. Distal özofageal leiomyomalarda cerrahi rezeksiyon etkili bir yöntemdir. 


\section{INTRODUCTION}

Benign tumors are uncommon pathologies with an estimated incidence of $1 \%$ in all esophageal neoplasms in the literature ${ }^{1}$. Leiomyoma is the most common of benign tumours (67\%-80\%) of the esophagus ${ }^{1,2}$. It arises from smooth muscle cells and the incidence is reported to be between $0.005 \%$ and $5.1 \%$ in large autopsy series ${ }^{3,}$ ${ }^{4}$. It is located mainly in the lower and middle thirds of the esophagus and, in most cases they are single lesions ${ }^{5}$. Leiomyoma can be diagnosed at any age while $90 \%$ of cases are between $20-69$ years. The peak incidence is usually in the third to fifth decades ${ }^{6}$. The male-to-female ratio is approximately $2: 1^{6,7}$. Most of them are smaller than $5 \mathrm{~cm}$ in-diameter and leiomyomas larger than $10 \mathrm{~cm}$ are defined as giant leiomyomas ${ }^{2,4,5}$. About half of the patients with leiomyoma are asymptomatic and malignant change is rare. The main symptoms are usually dysphagia and epigastric pain, but they are not specific for the disease. Endoscopic appearance is that of a mass covered by normal mucosa ${ }^{8}$.

The need to resect or not a leiomyoma is based on the symptoms it produces and on the differential diagnosis with Gastrointestinal Stromal Tumor (GIST) ${ }^{9}$. This report summarized the operative experience of distal esophageal leiomyoma performed resection in our department.

\section{MATERIAL AND METHODS}

The medical records of 6 patients with esophageal leiomyoma, operated between 2009 and 2014, were retrospectively analyzed. All patients underwent preoperative workup including upper gastrointestinal barium swallow, endoscopy, endoscopic ultrasonography (EUS) and dynamic computerized tomography (CT) scanning of the chest and abdomen.

Demographic features, clinical and laboratory findings including symptoms, diagnosis, histopathology, and results of surgical treatment were examined. Fine needle aspiration was not performed in any case.

\section{RESULTS}

There were six patients (two male and four female; $27-70$ years, mean age $48.8 \mathrm{yr}$ ); all patients were symptomatic whereas 4 patients suffered from dysphagia, two from dyspepsia and one from cough. All patients were subjected to the standard examinations, which demonstrated an esophageal tumor with features compatible with leiomyoma. The tumor is located at the distal third of the esophagus in all cases. In all cases, the masses were resected completely with a distal esophagectomy and esophagogastrostomy. Pyloroplasty was added to the procedure in all patients. In one patient, first of all, enucleation was applied but perforation was developed, then because of the wide mucosal defect the surgeon was decided to apply segmental resection. Frozen sections showed typical leiomyoma of the esophagus. In five patient lesions were single but in one patient there were six lesions in a short segment of esophagus; so we decided to resect effected segment of esophagus. The minimum size of tumor was $4 \mathrm{~cm}$, the maximum was $11 \mathrm{~cm}$. The mean in-hospital staying was 9 days. Postoperative follow-up did not reveal any mortality related to the primary diagnosis; pneumonia was occurred only in one patient and was alleviated with medication. Mean follow up period was 41, 6 months (14-66 months). Four patients were relieved from their symptoms, after surgical removal of the tumor. In follow up period, LA-grade A esophagitis was established in the other two patients, but these patients relieved from their symptoms by using of proton-pump inhibitors. Clinical presentation, diagnostic findings and management of the patients are summarized in Table 1.

\section{DISCUSSION}

Although leiomyoma is an uncommon pathology, it is the most common benign tumor of esophagus. It may be present in all parts of esophagus with an incidence 60 $\%$ in the distal third, $30 \%$ in the middle, and $10 \%$ in the proximal esophagus ${ }^{10}$. In this study, all lesions were localized in the distal third of esophagus and three of them reached under the z-line.

These tumors are usually found in middle age and are almost twice as common in men $^{7}$. Cystic or calcific degeneration may 
occur in leiomyoma but malign transformation is rare ${ }^{11}$. Leiomyomas grow slowly, and half of the patients are asymptomatic unless the tumor grows intramurally ${ }^{2,} 12$. Approximately one-half of all tumors are smaller than $5 \mathrm{~cm}$, but $5 \%$ may be larger than $10 \mathrm{~cm}^{7}$. Dysphagia with concomitant epigastric pain or retrosternal burning usually appears when the tumor's diameter becomes larger than the critical point of $4.5-5 \mathrm{~cm}^{13}$. In contrary to gastric leiomyomas, the bleeding of esophageal leiomyomas is rare because they do not ulcerate ${ }^{14}$. This presentation includes two men and four women with mean age of 48,8 years. The most common symptom was dysphasia, which was present in four cases. Only one lesion's size was $4 \mathrm{~cm}$, three of them were larger then $10 \mathrm{~cm}$ and in one patient multiple lesions were detected.

Leiomyoma has a radiological appearance characteristic of concave images and clear edges $^{12}$. Endoscopic ultrasonography should be combined with esophagogastroscopy to exclude esophageal cancer ${ }^{15}$. CT is useful for determining the tumor's size and its relationship with neighboring organs ${ }^{16}$. Differential diagnoses include foreign oppressed disease of esophagus, malignant esophageal tumors such as squamous or adenomatous carcinomas or leiomyosarcoma and other benign tumors. There are controversies about the need of preoperative biopsy for diagnosis ${ }^{13,14}$. In cases of ulcerated mucosa and suspicion of cancer, endoscopic biopsy is prescribed ${ }^{17}$. We evaluated our patients with upper gastrointestinal barium swallow, endoscopy, endoscopic ultrasonography and dynamic CT scanning of the chest and abdomen. Our policy is not to recommend endoscopic biopsy, because if we decide to enucleate the lesion the tumor is easily adhesive to the mucosa and the mucosal damage occurs accidentally during enucleation. In addition, accurate histopathological diagnosis could not be established with biopsy in many cases, especially for submucosal lesions.

Surgical treatment of leiomyomas is another debating issue. Some authors recommend resection in symptomatic patients and observation in asymptomatic patients with lesion smaller than $5 \mathrm{~cm}^{18}$, while oth- ers suggest resection even if it is asymptomatic due to possibility for transformation to malignancy ${ }^{13}$. We suggest that a leiomyoma should be removed when the patient is symptomatic or the lesion is larger than $3 \mathrm{~cm}$ even though the patient is asymptomatic. Histological and immunohistochemical examination is important to distinguish leiomyomas from GIST. Leiomyomas are not immunoreactive for c-kit, CD117 and CD34 in contrary of GIST ${ }^{4,5}$, 16 .

There are many treatment options depending on location and size of the tumor. Endoscopic mucosal resection or endoscopic submucosal dissection is reported to be effective in the treatment of small pedunculated tumors of 2-4 $\mathrm{cm}$ originating from the muscularis mucosae ${ }^{14,20}$. Symptomatic small leiomyomas $<5 \mathrm{~cm}$ can be enucleated either by open surgery ${ }^{13,18}$ or by means of video-assisted thoracoscopy (VATS) ${ }^{19}$. Myotomy of esophagus and extramucosal enucleation of the leiomyoma is the standard and established procedure ${ }^{13-18}$. Leimyomas at the proximal and middle third of esophagus can be resected via right thoracotomy while transhiatal approach is effective for the leimyomas located at the distal third $^{4,10}$.

Large tumors and tumors located at gastroesophageal junction can be treated with surgical resection of esophagus; the choices of this method depend on several factors ${ }^{7}, 14$ :

1) The esophageal leiomyoma is too large to allow a resection without damaging the mucosa,

2) Large leiomyomas locate in the distal esophagus and extend downward across the cardia,

3) For giant esophageal leiomyoma, it may have leiomyosarcoma-like transformation or with small leiomyosarcoma-like lesions and,

4) Multipl leiomyomas in a short segment of esophagus. To perform partial or subtotal resection of the esophagus, and esophagogastric anastomosis, the results are satisfactory.

This operation is typically performed with 
esophagectomy and gastric pull-up through left or right posterolateral thoracotomy. Gastric pull-up procedure is associated with complications including reflux esophagitis, stricture formation, dumping, diarrhea, reduced meal capacity, and weight $\operatorname{loss}^{21}$. So, while some authors don't prefer pyloroplasty after resection ${ }^{22}$, others prefer esophageal replacement with colon for the leiomyomas located in the upper third of esophagus and if the mucosa is damaged by the lesion ${ }^{7}$. We suggest that the resection must be done for large tumors and multiple tumors in a short segment of esophagus. In our presentation, four patients had a leiomyoma larger then $5 \mathrm{~cm}$ and three of them were giant leiomyoma. One patient had multiple lesions and one patient had a leiomyoma smaller then $5 \mathrm{~cm}$ but we couldn't differentiate from GIST by EUS, preoperatively. In all patients, the lesions were resected using a thoracoabdominal approach, and a distal esophagectomy and esophagogastrostomy were performed. Pyloroplasty was added the procedure in all patients. All of the six patients recovered approvingly with no mortality and resumed normal diet after operation. In one patient, pneumonia was occurred and was treated with medication. In follow-up period, we established esophagitis in only two patients; their symptoms were alleviated by using of proton-pump inhibitors.

In conclusion; once the clinical diagnosis of leiomyoma is established, the surgical management should be defined according to the patients'suffers and lesion characteristics. Currently, resection via thoracoabdominal approach is recommended for large and multiple tumors located at the distal-esophagus.

Table1: (EGS: esophagogastroscopy; EUS: endoscopic ultrasonography ; PPI: proton-pump inhibitors; LA-A esophagitis :classification of esophagitis based on LA Classification).

\begin{tabular}{|c|c|c|c|c|c|c|c|}
\hline $\operatorname{Sex}$ & $\begin{array}{l}\text { Age } \\
\text { (year) }\end{array}$ & Symptoms & Diameter(cm) & $\begin{array}{l}\text { Localization } \\
\text { (EGS-EUS) }\end{array}$ & Treatment & $\begin{array}{l}\text { Follow up } \\
\text { period } \\
\text { (month) }\end{array}$ & $\begin{array}{l}\text { EGS find- } \\
\text { ings and } \\
\text { usage of } \\
\text { PPI }\end{array}$ \\
\hline $\mathrm{F}$ & 27 & $\begin{array}{l}\text { Dysphagia, } \\
\text { caugh }\end{array}$ & $10 \times 5,5 \times 5$ & $32-40$ & Ivor-Lewis & 14 & $\begin{array}{l}\text { LA-A } \\
\text { esophagitis; } \\
\text { PPI(+) }\end{array}$ \\
\hline $\mathrm{F}$ & 44 & Dyspepsia & $11 \times 5 \times 4,5$ & $31-40$ & Ivor-Lewis & 18 & $\begin{array}{l}\text { Normal; } \\
\text { PPI(-) }\end{array}$ \\
\hline M & 64 & Dysphagia & $\begin{array}{l}6 \text { lesions, ranging from } 3 \\
\mathrm{~mm} \text { to } 3 \mathrm{~cm}\end{array}$ & $30-38$ & Ivor-Lewis & 46 & $\begin{array}{l}\text { Normal; } \\
\text { PPI(-) }\end{array}$ \\
\hline M & 70 & Dyspepsia & $5,5 \times 3,5 \times 2$ & $\begin{array}{l}40 \text {-under } \mathrm{z}- \\
\text { line }\end{array}$ & $\begin{array}{l}\text { Ivor- } \\
\text { Lewis1 }\end{array}$ & 47 & $\begin{array}{l}\text { Normal; } \\
\text { PPI(-) }\end{array}$ \\
\hline $\mathrm{F}$ & 44 & Dysphagia & $4 \times 3 \times 2$ & $\begin{array}{l}\text { 40-under } \mathrm{z}- \\
\text { line }\end{array}$ & $\begin{array}{l}\text { Ivor- } \\
\text { Lewis2 }\end{array}$ & 59 & $\begin{array}{l}\text { Normal; } \\
\text { PPI(-) }\end{array}$ \\
\hline $\mathrm{F}$ & 44 & Dysphagia & $11 \times 4 \times 2,5$ & $\begin{array}{l}\text { 36-under } \mathrm{z}- \\
\text { line }\end{array}$ & Ivor-Lewis & 66 & $\begin{array}{l}\text { LA-A } \\
\text { esophagitis; } \\
\text { PPI(+) }\end{array}$ \\
\hline
\end{tabular}

\section{REFERENCES}

1. Mutrie CJ, Donahue DM, Wain JC, Wright CD, Gaissert HA, Grillo HC, Mathisen DJ, Allan JS. Esophageal leiomyoma: a 40-year experience. Ann Thorac Surg 2005; 79:1122-5.

2. Aurea P, Grazia M, Petrella F, Bazzocchi R. Giant leiomyoma of the esophagus. Eur J Cardiothorac Surg 2002; 22:1008-10.

3. Lee LS, Singhal S, Brinster CJ,
Marshall B, Kochman ML, Kaiser LR, Kucharczuk JC. Current management of esophageal leiomyoma. J Am Coll Surg 2004; 198:136-46.

4. Karagülle E,Akkaya D,Türk E, Göktürk HS, Y1ldırım E, Moray G. Giant leiomyoma of the esophagus: A case report and review of the literature. Turk J Gastroenterol 2008; 19: 180-3.

5. Hatch GF 3rd, Wertheimer-Hatch 
L, Hatch KF, Davis GB, Blanchard DK, Foster RS, Skandalakis JE. Tumors of the esophagus. World J Surg 2000; 24: 401-11.

6. Lawrence SL, Sunil S, Clayton JB, Blair M, Michael LK, Larry RK. Current management of esophageal leiomyoma. J Am Coll Surg 2004; 198: 136-46.

7. Cheng BC, Chang S, Mao ZF, Li MJ, Jie Huang, Wang ZW, Wang TS. Surgical treatment of giant esophageal leiomyoma. World J Gastroenterol 2005; 11: 4258-60.

8. Rice TW. Benign esophageal tumors: esophagoscopy and endoscopic esophageal ultrasound. Semin Thorac Cardiovasc Surg 2003; 15:20-6.

9. Zaninotto G, Portale G, Constantini M, Rizzetto C, Salvador R, Rampado S, Pennelli G, Ancona E. Minimally invasive enucleation of esophageal leiomyoma. Surg Endosc 2006; 20: 1904-8.

10. Peters JH, DeMeester TR. Esophagus and diaphragmatic hernia. In: Brunicardi FC, Andersen KD, Billiar RT, Dunn LD, Hunter GC, Pollock RE, eds. Schwartz's Principles of Surgery. 8th ed. New York: McGraw-Hill 2005; 906.

11. Nagashima R, Takeda H, Motoyama $\mathrm{T}$, Tsukamoto $\mathrm{O}$, Takahashi T. Coexistence of superficial esophageal carcinoma and leyomyoma: case report of an endoscopic resection. Endoscopy 1997; 29:683-4.

12. Jang KM, Lee KS, Lee SJ, Kim EA, Kim TS, Han D, Shim YM. The spectrum of benign esophageal lesions: imaging findings. Korean J Radiol 2002; 3: 199-210.

13. Asteriou C, Konstantinou D, Lalountas M,Kleontas A, Setzis K, Zafiriou G, Barbetakis N. Nine years experience in surgical approach of leiomyomatosis of Esophagus. World Journal of Surgical Oncology 2009; 7: 102.

14. Sun X, Wang J, Yang G. Surgical treatment of esophageal leiomyoma larger than $5 \mathrm{~cm}$ in diameter: $\mathrm{A}$ case report and review of the liter- ature. J Thorac Dis 2012; 4: 323-6.

15. Wang Y, Sun Y, Liu Y, Li Y, Wang Z. Transesophageal intraluminal ultrasonography in diagnosis and differential diagnosis of esophageal leiomyoma. Zhonghua Yixue Zazhi 2002; 82: 456-8.

16. Loviscek LF, Yun JH, Park YS, Chiari A, Grillo C, Cenozb MC. Leiomyoma of the oesophagus. CIR ESP 2009; 85: 147-51.

17. Punpale A, Rangole A, Bhambhani N, Karimundackal G, Desai N, Ashwin de Souza, Pramesh CS, Jambhekar N, Mistry RC. Leiomyoma of esophagus. Ann Thorac Cardiovasc Surg 2007; 13: 78-81.

18. Priego P, Lobo E, Alonso N, Gil Olarte MA, Pérez de Oteyza J, Fresneda V. Surgical treatment of esophageal leiomyoma: an analysis of our experience. Rev Esp Enferm Dig 2006; 98: 350-8.

19. Taniguchi E, Kamiike W, Iwase K, Nishida T, Akashi A, Ohashi S. Thoracoscopic enucleation of a large leiomyoma located on the left side of the esophageal wall. Surg Endosc 1997; 11: 280-2.

20. Shin CS, Jung IS. Endoscopic removal of submucosal tumors: preprocedure diagnosis, technical options, and results. Endoscopy 2005; 37: 646-54.

21. Watson TJ, Peters JH, DeMeester TR. Esophageal replacement for end-stage benign esophageal disease. Surg Clin North Am 1997; 77: 1099-113.

22. Johnson WH, Fecher AM, McMahon RL, Grant JP, Pryor AD. VersaStep trocar hernia rate in unclosed fascial defects in bariatric patients. Surg Endosc 2006; 20: $1584-6$. 